\title{
MAIN PRINCIPLES OF COMPETENCY BASED ENGLISH LANGUAGE TEACHING IN HIGHER EDUCATION
}

\section{ОСНОВНІ ПРИНЦИПИ КОМПЕТЕНТІСНО ОРІЄНТОВАНОГО ВИКЛАДАННЯ АНГЛІЙСЬКОї МОВИ У ВИЩІЙ ШКОЛІ}

\begin{abstract}
The authors of the article outline the main aspects and characteristics of competencybased English language teaching, which is one of the most important means for the modernization of educational process. It foresees teaching a set of language skills, that are necessary for individuals to function proficiently in the society. The approaches to the notion of "competency" are analyzed. Competencies are seen as a mix of complex cognitive skills and attitudes that allow someone to show competent behavior in a particular domain or profession.

Special attention is given to the curriculum of competency-based education which contains a variable class structure in contrast to the standardized class structure in traditional education. Three stages of implementing competency-based language teaching are thoroughly examined. The stages pertain the design of learning tasks, their delivery and the diagnosis of learners' progress.
\end{abstract}

The design of learning tasks and a competencybased curriculum is at the heart of competencybased teaching. The necessity of creating a constructive learning environment and providing effective support is emphasized. In a competency-based approach the learners become the subjects rather than the objects of the educational process. It addresses what the learners are expected to do rather than what they are expected to learn about. More opportunities for an interdisciplinary approach and a smooth transferring to new problem situations should be provided. The pros and cons of a competencybased approach are elaborated in details. Competency-based language teaching focuses on competencies and outputs. It addresses the language as a tool for communication rather than on language knowledge as an end in itself. Competency-based language teaching is gaining popularity nowadays. It is proved that through the clearly defined outcomes and continuous feedback, the quality of assessment the students' learning as well as teaching are improved. No doubt, the matter of improving learning competencies and skills will remain one of the world's fastest growing activities and priorities in the future.

Key words: competency, competency-based teaching, competency-based education, competent performance, curriculum.

Стаття окреслює основні аспекти та характеристики компетентнісно орієнтованого підходу до викладання англійської мови, що є одним із важливих засобів модернізації освітнього процесу. Це передбачає навчання низки мовних навичок, що є необхідними для компетентного функціонування індивідуумів у суспільстві. Проаналізовано різні підходи до поняття «компетентність». Компетентності розглядаються як поєднання складних когнітивних навичок та ставлень, що дозволяють проявляти компетентну поведінку у певній царині чи профресіi.

Особливу увагу приділено програмі компетентнісно орієнтованого навчання, яка передбачає різноманітну структуру занять, на відміну від стандартної структури у традиційному навчанні. Розглянуто три етапи запровадження компетентнісно орієнтованого викладання англійської мови, що стосуються розробки та укладання навчальних завдань, їх подання та визначення рівня успішності.

Укладання навчальних завдань та компе тентнісно орієнтованих навчальних програм $\epsilon$ в центрі компетентнісно орієнтованого викладання. Наголошується на необхідності створення конструктивного навчального середовища та забезпечення ефективної підтримки. При компетентнісно орієнтованому підході учасники $\epsilon$ більше суб'єктами, ніж об'єктами освіт нього прочесу. Передбачається більше можливостей для міждисциплінарного підходу та забезпечення безперешкодного переходу до вирішення нових завдань. Визначено основні переваги та недоліки застосування компетентнісно орієнтованого підходу у навчальному процесі.

Компетентнісно орієнтоване викладання мови націлене на формування компетентностей та отримання результатів. Більше уваги приділяється мові як засобу комунікації, а не теоретичним мовним знанням. Нині компетентнісно орієнтоване викладання мови набирає популярність. Доведено, що завдяки чітко визначеним иілям та постійній підтримці, якості оцінювання покращується процес навчання та викладання.

Безсумнівно питання вдосконалення навчальних компетентностей та навичок залишатимуться вагомим видом діяльності та пріоритетом у майбутньому.

Ключові слова: компетентність, компетентнісно орієнтоване викладання, компетентнісно орієнтована освіта, компетентна діяльність, навчальна програма.
Department

Lviv Polytechnic National University
Stating the problem. Competency-based language teaching is an application of the principles of competency-based education to language teaching, which focuses on the outcomes or outputs of learning. By the end of the 1970s it was mostly used in work-related language teaching programs for adults but since the 1990s it has been seen first of all as the state-of-the art approach to adult ESL. Competency-based teaching foresees teaching a set of language skills, that are necessary for individuals to function proficiently in the society. Therefore, the focus is on how the students can use the language instead of their knowledge about the language. A key characteristic of competency-based teaching is its focus on mastery. In this system, students are not allowed to continue until they have demonstrated mastery of the identified competencies. Thus, the definition of a competency-based teaching is closely 
tied to mastery learning. It is an approach to education that focuses on the student's demonstration of desired learning outcomes as central to the learning process. Currently, there is a clear trend towards competencybased language teaching.

Analysis of the research. Competency-based language teaching has been of great interest to the following linguists: E. R. Auerbach [1], C. Braslavsky [2], Jeroen J.G. van Merriënboer [4], K. Keen [5], J. C. Richards \& T. S. Rodgers [8], and many others. Most of the studies are concentrated on describing the essence of the notion «competency» and revealing the main points of the competency-based approach in language education. As claimed by Richards \& Rodgers [8, p. 143], language learning always needs to be connected to the social context it is used in. Furthermore, language is seen as a medium of interaction and communication between people who want to achieve specific goals and purposes. This especially applies to situations in which the learner has to fulfill a particular role with language skills, which can be predicted or determined for the relevant context.

The Oxford Advanced Learner's Dictionary defines competence as "the ability to do something well" and as "a skill that you need in a particular job or for a particular task" [7, p. 246]. According to Jeroen J.G. van Merriënboer [4, p. 12], competencies are a mix of complex cognitive skills, interpersonal skills, and attitudes that allow someone to show competent behavior in a particular domain or profession. The work of $\mathrm{K}$. Keen [5] indicates that competent performance foresees dealing with non-routine and abstract work processes, handling decisions and responsibilities, operating in ever-changing environments, dynamic systems, understanding and working in groups. Besides, it is worth mentioning that competent performance always demands complex cognition, which is best reflected in the ability to recognize new problems and find creative solutions for solving them. Simply said, competencybased teaching aims at the development of such competencies. In the framework of competencybased teaching, the educational approach shifts from knowledge transfer to providing the student with the knowledge, skills, and attitudes that enable problem solving in a future job context [5]. This shift at the level of learning significantly impacts the teaching-learning process and the content that will drive the learning experience.

E. R. Auerbach [1, p. 414-415] examines eight key descriptors of competency-based education: a focus on successful functioning in society, a focus on life skills, task or performance-centered orientation, modularized instruction, explicit outcomes, continuous and ongoing assessment, demonstrated mastery of performance objectives and individualized, studentcentered instruction.
The aim of the paper is to outline the main principles of competency-based English language teaching and substantiate their significance and efficiency as regards language training in higher education.

The body of the paper. The implementation of competency-based teaching takes many forms. In some cases, it is a total system in which all teaching and learning activities are related to the development of specific competences. We know that curriculum, as a broad concept that includes processes and results, is the hub of educational change [2, p. 2]. The curriculum of competency-based education contains variable class structure and testing of subject matter at different levels while traditional education presupposes standardized class structure. Before considering competency-based language teaching, it is necessary to clarify what is meant by competency. The concept of competency is a pillar and an organizing principle of a curriculum. It is defined as the development of complex capabilities that enable students to think and act in various fields of activity. It consists of achieving knowledge in action, the result of a sound knowledge base that can be put into practice and used to explain what is happening. In a competency-based curriculum, exit profiles specify the classes of situations that learners must be able to handle competently by the end of their education. Depending on the type of education, these classes of situations are identified either on the basis of real-life or work-related situations or on the internal logic of the discipline under consideration. The conventional knowledge-based approach presupposes that curriculum is mainly implemented by having students reproduce theoretical knowledge and memorize facts.

In our opinion, the following three stages must be considered in order to implement competency-based teaching in English language classes:

1) How to design learning tasks;

2) How to deliver such tasks;

3) How to diagnose further learners' progress.

Regarding the design of learning tasks it is necessary for a teacher to combine three directions, namely: uniting the world of knowledge and the world of work in learning, building learner support that works, promoting the development of higherorder skills. They can be viewed as urgent goals that must be attained if it comes to the development of competency-based education [4, p. 14].

The design of learning tasks is thus at the heart of competency-based learning and a competencybased curriculum. Learning tasks aiming at the development of competencies must involve complex learning. The acquisition of cognitive, interpersonal and constituent skills, the formation of attitudes and values should be formed in a simultaneous integrated process. Such integration of all aspects will allow the transition to solving new problems and 
situations. There is a variety of learning tasks types to choose from. The most important of which refer to case studies analysis, models of problem-based and project-oriented learning.

The traditional approach to the design of learning tasks is to some extent straightforward and familiar to most of us. It concentrates on knowledge of a particular subject matter, analyzes and systematizes it. Learning is mainly reading and understanding these teaching materials. Besides, learning tasks have the form of assignments and practice items that are added for learning during reading. A unit has a constant structure, which is used as the model for further units. The main output of the learning process is a highly structured description of the subject matter.

On the one hand, this approach is neat, conveniently arranged and familiar. On the other hand, knowledge is not something that can simply be described in a course book and then be transmitted to learners. Reading a course book is hardly the best learning task. Instead, knowledge must be constructed by the learners, that is learning tasks and meaningful problem solving can help them to do so.

The role of a teacher is to create a constructive learning environment in which learners work on relatively complex meaningful learning tasks. Besides, it should provide more opportunities for an interdisciplinary approach and a smooth transferring to new problem situations. The content of the "authentic" learning tasks should involve more practical experience and skills than pure theoretical knowledge. The learning tasks should more or less copy the tasks that students will encounter in their professional post-academic life.

Within the competency-based approach, the learning tasks that are given to students are much more complex and time consuming than the assignments or practice items that can be found in a typical study book. In order to fruitfully work on the tasks learners need support - and we clearly need to build support that works. It seems likely that support must be fully embedded in the learning task or learning environment in order to be effective [6]. You should divide a complex learning task in subtasks. Embedded support is given by decomposing the learning task in phases. Secondly, sequencing learning tasks should range from simple to complex. Thirdly, you should mind the nature of the learning task itself. It should be connected with a real-world solution for a given problem provides more support than a conventional problem.

It is worth mentioning that first-order skills are bound to a particular learning domain, higher-order skills seem incorrectly to be independent of any domain [4, p. 17]. If this is true, higher-order skills can only be trained in a particular domain.

What concerns the delivery of competency-based learning tasks, a number of technologies can be used to support competency-based language teaching. You should deliver in multimedia learning environment, which evolves from programmed tutorials, drilland- practice computer-based training, hypertext systems, and intelligent tutoring systems towards simulation-based learning environments. Web-based teaching is the center of interest because it facilitates distance delivery and combine presentation and communication facilities [4, p. 18].

Three new directions will be formulated with regard to the diagnosis of learner progress. All three of them should be viewed as challenges that must be attained in successful competency-based teaching. Namely, providing meaningful feedback, using tests for complex performances, assuring the quality of competency-based learning.

It is known that feedback is then most effective when it is provided immediately after performance. And in case of incorrect performance, feedback should explain why there was an error and give hints for how to reach the correct goal $[4$, p. 18].

It is worth mentioning the fact that in a competencybased approach the performance on a rich learning task is never right or wrong it is merely more or less effective, efficient or satisfactory.

D. L. Butler \& P. H. Winne [3] presented an interesting model for providing so-called cognitive feedback to students in such a way that it promotes self-regulated learning from rich learning tasks. The central idea is that feedback should provide students with information that allows them to link particular "cues" to the quality of their performance. Cues may, for instance, concern features of the task, the learning activities or the cognitive processes the learners were engaged in.

Finally, we should test how we teach. Tasks for testing must mimic the rich learning tasks used for learning, and students must be judged on their complex performances. In a competency-based curriculum, the competencies are expected to be developed throughout the whole curriculum. Student dossiers can thus no longer be a simple file with pass/ fail results for each course, but must keep track of student progress in a much more detailed fashion.

Learner diagnosis with the purpose of making placement decisions is especially important. It supports teaching in a highly heterogeneous group of students. Performance-based assessment procedures may better help students to determine their suitability for a particular course.

We should acknowledge that lists of independent learning goals could never form the basis for competency-based learning. Instead, the starting point for competency-based learning must be a highly integrated network of learning goals that stresses the relationships between those goals and learner activities must be designed in such a way that they stimulate the construction of such a network. In this 
regard it is vital that every competency is mastered one at a time because this makes sure that the learners know what they have already learned and what the next steps will look like.

Conclusions. Competency-based language teaching is an outcome-based approach. The learning activities used in it can be described as systematically designed activities to achieve a certain competence. These activities are real-world tasks, which may be related to any domain of life. Typical areas, for which such competency-based activities are for example job application, job interview or work schedules. All these areas presuppose a collection of units of competences, which include specific knowledge, thinking processes, attitudes, perceptual and physical skills.

The task of the teacher in competency-based language teaching is to design a syllabus and to select learning activities according to the competency the students are going to acquire, to provide positive and constructive feedback in order to help the students improve their skills.

The role of the learner in a competency-based framework is to decide whether the competences are useful and relevant for him/her. This means that the learner has an active role in the classroom which is underlined by the fact that the students are expected to perform the skills learned.

There are both critics and supporters of competency-based language teaching. On the one hand, it is obviously very difficult to develop lists of competencies for every situation. Besides, describing an activity in terms of a set of different competencies is not enough in order to deal with the complexity of the activity as a whole. But on the other hand, competency-based language teaching is gaining popularity in the whole world. It is argued that through the clearly defined outcomes and continuous feedback, the quality of assessment as well as the students' learning and teaching are improved. These improvements can be seen on all educational levels.

It should be emphasized that the matter of improving learning competencies and skills will remain one of the world's fastest growing activities and priorities in the future.

\section{REFERENCES:}

1. Auerbach E. R. Competency-based ESL: One step forward or two steps back? TESOL Quarterly. 1986. Vol. 20, № 3. P. 411-430.

2. Braslavsky C. A new stage in the IBE's capacitybuilding activities: Moving forward on the Community of Practice and networked communication in curriculum development. Educational Innovation and Information. 2005. Number 119-120. P. 2-10.

3. Butler D. L., \& Winne P. H. Feedback and selfregulated learning: A theoretical

4. Jeroen J. G. van Merriënboer. ID for Competencybased Learning: New Directions for Design, Delivery and Diagnosis. Interactive Educational Multimedia. 2001. № 3. P. 12-26.

5. Keen K. Competence: What is it and how it can be developed? In J. Lowyck, P.de Potter, \& J. Elen (Eds.). Instructional Design: Implementation issues. Brussels: IBM International Education Center, 1992. P. 111-122.

6. Martens R. L., \& Valcke M. A. Validation of a theory about functions and effects of embedded support devices in distance learning materials. European Journal for the Psychology of Education. № 10. 1995. P. 181-196.

7. Oxford Advanced Learner's Dictionary of Current English / Ed. by A. S. Hornby. Oxford: Oxford University Press, 1989. 1579 p.

8. Richards J.C., \& Rodgers T.S. Approaches and Methods in Language Teaching (Second Edition). Cambridge: Cambridge University Press, 2001. 148 p. 